\title{
Paradoxical Inhibition among Bacteria. Characterization of the Phenomenon and Nature of the Genetic Process
}

\author{
By A. N. CHAKRABARTY \\ Division of Microbiology, Indian Institute of Experimental Medicine, \\ Calcutta-32, India \\ AND \\ SUJATA G. DASTIDAR \\ Division of Microbiology, Jadavpur University, Calcutta-32, India
}

(Received 12 January 1973; revised 29 August 1973)

\begin{abstract}
SUMMARY
The phenomenon of paradoxical inhibition (p.i.) manifests itself as well-defined growth of a sensitive bacterium in the centre of the zone of inhibition overlying an area of growth of the inhibitory bacterium. Bacteriocin typing medium (BTM) for Vibrio cholerae elicited p.i. for this group only. A medium for paradoxical inhibition (MPI) was devised which supported the development of p.i. among members of Enterobacteriaceae, Vibrio and Alcaligenes spp. at high frequency. The reacting pair of strains could belong either to the same or to different genera. Colonies of non-bacteriocinogenic strains derived from the central area of p.i. showed acquisition of bacteriocinogeny at high frequency. Acquisition was rapid in the beginning (up to $4 \mathrm{~h}$ ) followed by a decline and virtual disappearance of bacteriocinogeny by $I 8 \mathrm{~h}$ on MPI, but was substantially retained on BTM. The overall frequency of acquisition among cell populations of different strains varied between $\mathrm{IO}^{-1}$ and $\mathrm{IO}^{-4}$, and the acquired characters were stable. Acquisition did not require either cell contact or participation of phages, but depended upon extracellular diffusable agents that were DNase sensitive and RNase resistant. A mutational basis for such acquisition could be ruled out, and the process of gene transfer was considered to be transformation. The extra-chromosomal nature of the determinants of bacteriocinogeny in the bacteria studied was suggested by effective elimination of these markers by sodium dodecyl sulphate and acridine orange.
\end{abstract}

\section{INTRODUCTION}

Growth in the centre of the zone of inhibition of indicator strains produced by bacteriocinogenic cultures has been reported among Escherichia coli (Fredericq, 1948), Shigella sonnei (Abbott \& Shannon, 1958), Pseudomonas aeruginosa (Wahba, 1963) and Vibrio cholerae (Chakrabarty, Adhya, Basu \& Dastidar, 1970). Chakrabarty et al. (1970) designated the phenomenon as paradoxical inhibition (p.i.) characterized by a narrow central band of growth overlying the area of primary growth and flanked by areas of inhibition with bilateral peripheral growths (see Fig. 3, below). For any pair of bacteriocinogenic and indicator vibrios producing p.i., the phenomenon was reproducible. The objects of the present study were: to determine conditions for development of p.i. among several groups of Gramnegative bacteria, to study morphological details of the different components of p.i., and to elucidate the genetic process that may underlie the mechanism of its development. 
Table I. Source of cultures

\begin{tabular}{|c|c|c|c|}
\hline Culture & $\begin{array}{l}\text { No. of } \\
\text { strains }\end{array}$ & Source & $\begin{array}{l}\text { Criterion for identification } \\
\text { (reference) }\end{array}$ \\
\hline Vibrio cholerae* NIH35A3, KI I & 2 & $\begin{array}{l}\text { S. Mukerjee, } \\
\text { Calcutta, } \\
\text { India, }\end{array}$ & \multirow{5}{*}{$\begin{array}{l}\text { International Association } \\
\text { of Microbiological } \\
\text { Societies, Sub-committee } \\
\text { on Taxonomy of Vibrios } \\
\text { (I966). }\end{array}$} \\
\hline $\begin{array}{l}\text { V. cholerae } 540, \dagger 541,547 \text {, } \\
564 \dagger, 847,852, \text { I } 352, \text { I } 4033 \ddagger\end{array}$ & 8 & $\begin{array}{l}\text { Ranjit Sen, } \\
\text { Calcutta, } \\
\text { India }\end{array}$ & \\
\hline V. cholerae $569 \mathrm{~B}$ & $\mathbf{I}$ & $\begin{array}{l}\text { N. K. Dutta, } \\
\text { Bombay, } \\
\text { India }\end{array}$ & \\
\hline $\begin{array}{l}V . \text { cholerae bacteriocinogenic } \\
\text { prototypes: IA, IB, IC, 2A, 2B, } \\
3,4,5,6,7 \text { and } 8\end{array}$ & II & Authors & \\
\hline V. cholerae $675, \dagger 769 \dagger$ & 2 & Authors & \\
\hline 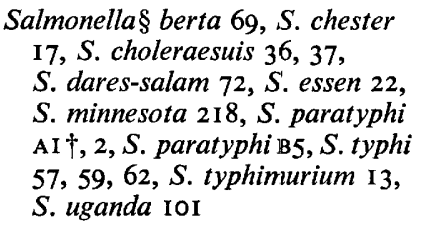 & 15 & $\begin{array}{l}\text { Joan Taylor, } \\
\text { London }\end{array}$ & Cowan \& Steel (1965) \\
\hline Shigella flexneri 38 & $\mathbf{I}$ & Authors & Cowan \& Steel (1965) \\
\hline Sh. flexneri $3189 \dagger, 30225 \dagger$ & 2 & $\begin{array}{l}\text { A. Vertényi, } \\
\text { Pécs, Hungary }\end{array}$ & Cowan \& Steel (1965) \\
\hline Sh. sonnei 17,56 & 2 & $\begin{array}{l}\text { J. D. Abbott, } \\
\text { Manchester }\end{array}$ & Cowan \& Steel (1965) \\
\hline Sh. sonnei $\mathrm{M} 2 / \mathrm{I}, \mathrm{M} 2 / 2, \mathrm{M} 56$ & 3 & Authors & Cowan \& Steel (1965) \\
\hline Proteus mirabilis & $19,6 \dagger$ & Authors & Cowan \& Steel (1965) \\
\hline Escherichia coli Row† (KI2) & I & $\begin{array}{l}\text { J. D. Abbott, } \\
\text { Manchester }\end{array}$ & Cowan \& Steel (1965) \\
\hline E. coli 055: В5, О1 II： в4† & 4 & Authors & Cowan \& Steel (1965) \\
\hline E. coli $\mathrm{C} 2 \mathrm{I}, \mathrm{C} 22, \mathrm{C} 25, \mathrm{c} 35, \mathrm{~K} 22$ & 5 & Authors & Cowan \& Steel (1965) \\
\hline Alcaligenes faecalis $8748 \ddagger$, $9220 \ddagger$ & 2 & $\begin{array}{l}\text { R. Hugh, } \\
\text { Washington } \\
\text { D.C., U.S.A. }\end{array}$ & Leifson (1958) \\
\hline A. denitrificans $13138 \%$ & I & R. Hugh & Leifson (1958) \\
\hline Alcaligenes spp. $1083^{\prime}+$ & $\mathbf{I}$ & R. Hugh & Leifson (1958) \\
\hline
\end{tabular}

\section{METHODS}

Bacteria. The strains used are described in Table $\mathrm{I}$. The majority were received as stabslant cultures, but the Alcaligenes spp. were received as freeze-dried ampoules. All were checked for purity and identified where necessary (see Table I). Stock cultures were maintained at $4{ }^{\circ} \mathrm{C}$ as stab-slants of $\mathrm{I} \%$ peptone, I $\%$ agar and $0.5 \% \mathrm{NaCl}$ in distilled water, $\mathrm{pH} \mathrm{7.4.} \mathrm{The} \mathrm{strains} \mathrm{used} \mathrm{in} \mathrm{genetic} \mathrm{studies} \mathrm{were} \mathrm{preserved} \mathrm{in} \mathrm{a} \mathrm{freeze-dried} \mathrm{state.}$

Media. The bacteriocin typing medium (BTM) for Vibrio cholerae (Chakrabarty et al. 
1970) consisted of $\mathrm{IO}^{-5} \mathrm{M}$-iodoacetic acid (final concentration), $0.6 \%$ each of tri-sodium citrate and $\mathrm{K}_{2} \mathrm{HPO}_{4}$, and $\mathrm{I} \cdot 5 \%$ tryptic soy broth (Difco, Detroit, U.S.A.) in $\mathrm{I} \cdot 5 \%$ agar (Difco), $\mathrm{pH} 7 \cdot 5$ to $7 \cdot 6$. Tryptic soy agar (TSA) used for enterobacteria consisted of $\mathrm{I} \cdot 5 \%$ tryptic soy broth (Difco) in $\mathrm{I} \cdot 5 \%$ agar (Difco), $\mathrm{pH} 7.5$. These two media were dispensed in 20 and $9 \mathrm{ml}$ amounts respectively in 80 and $45 \mathrm{~mm}$ Petri dishes; larger plates were used for preliminary studies on p.i., assay, screening tests and determination of inhibition patterns (see below); smaller ones were used for all other studies. For studies on optimal development of p.i., four basic media were used: (i) tryptone soya broth (Oxoid, $\mathrm{CM}_{129}$ ) $2 \%$, (ii) tryptone (Oxoid, $\mathrm{L}_{42}$ ) $2 \%$, (iii) casein hydrolysate (Oxoid, $\left.\mathrm{L}_{41}\right) 2 \%$ plus yeast extract (Oxoid, $\mathrm{L}_{20}$ ) $0.5 \%$ and (iv) a nutrient broth containing $\mathrm{I} \%$ beef extract (Oxoid, $\mathrm{L}_{30}$ ), I \% peptone (bacteriological; Oxoid, $\mathrm{L}_{37}$ ) and $0.5 \% \mathrm{NaCl}$ (Analar). All were solidified with $1 \%$ agar (Oxoid, no. $3, \mathrm{~L}_{13}$ ) and tested with various concentrations of chemicals as listed in Table 2. The basic medium adopted for further studies on p.i. was nutrient agar (iv) plus $0.05 \%$ sodium dodecyl sulphate (SDS) and $0.02 \%$ ethylene diamine tetraacetic acid (EDTA), $\mathrm{pH} 7 \cdot 4$ to $7.5 ; 9 \mathrm{ml}$ portions of medium were placed in $45 \mathrm{~mm}$ Petri dishes. This was designated as medium for paradoxical inhibition (MPI).

Basic technique for demonstration of p.i. The bacteriocinogenic (primary) strain was streaked across the appropriate medium and incubated for 44 to $72 \mathrm{~h}$, depending on the strain used, then refrigerated at $4{ }^{\circ} \mathrm{C}$ for $\mathrm{i} 8$ to $24 \mathrm{~h}$. The primary growth was then removed with the edge of a sterile glass slide, and the plate exposed to chloroform vapour for $2 \mathrm{~h}$ and then aerated for $2 \mathrm{~h}$. The indicator (secondary) bacteria were then applied.

Secondary bacteria likely to give p.i. were used as I $8 \mathrm{~h}$ peptone-water cultures. For the screening tests, these cultures were applied with a loop as parallel streaks at right-angles to the primary streak; seven to eight streaks were used for larger plates and five to six for the smaller ones. When a continuous band of central growth of a single secondary bacterium was desired, $45 \mathrm{~mm}$ Petri dishes were inoculated in one of two ways: (i) multiple overlapping streaks, Io to $\mathrm{I} 2$ in number from the same culture suspension (Fig. I); and (ii) by a sterile filter-paper disc (Whatman no. I, $40 \mathrm{~mm}$ in diameter) evenly moistened with $0 . \mathrm{I} \mathrm{ml}$ of $10^{-1}$ dilution of the culture suspension, dried for $\mathrm{Io} \min$ at $37^{\circ} \mathrm{C}$, placed for I to $2 \mathrm{~min}$ on the agar surface and then removed with sterile forceps.

Assay procedures. Bacteriocin-resistant and total colony counts were based on the methods of Miles \& Misra (1938). The assay media for bacteriocin resistant colony counts were BTM for vibrios and TSA for enterobacteria, on which appropriate primary bacteriocinogenic bacteria had been allowed to grow and produce bacteriocin. For this purpose the basic technique was followed, but the primary bacteria were grown for $72 \mathrm{~h}$ and the plates then stored in the refrigerator for $48 \mathrm{~h}$ prior to the assay tests, to ensure a uniform concentration of bacteriocins throughout the medium. Six dilutions of a particular sample were tested on each plate, taking care to avoid the central zone (about $2 \mathrm{~cm}$ ) of BTM. Total colony counts were performed in triplicate on nutrient agar. Appropriate sensitive organisms were used as controls.

Extraction of bacteriocins from media for assay purposes was based on the technique of McGeachie \& McCormick (I963). After completion of the basic technique (see above) prior to application of secondary organisms, blocks of media $\mathrm{I} \mathrm{cm}$ wide were removed from the central area (underlying the primary growth) and inhibition and peripheral zones of TSA, BTM and MPI, chopped into small pieces and frozen at $-20^{\circ} \mathrm{C}$. The fluid obtained on thawing was centrifuged to remove pieces of agar. Twofold dilutions of the supernatant were made in peptone-water and titrated by the method of Goebel \& Barry (I958). The highest dilution $(0.01 \mathrm{ml})$ giving a clear zone of inhibition indicated the bacteriocin titre. 
A. N. CHAKRABARTY AND S. G. DASTIDAR

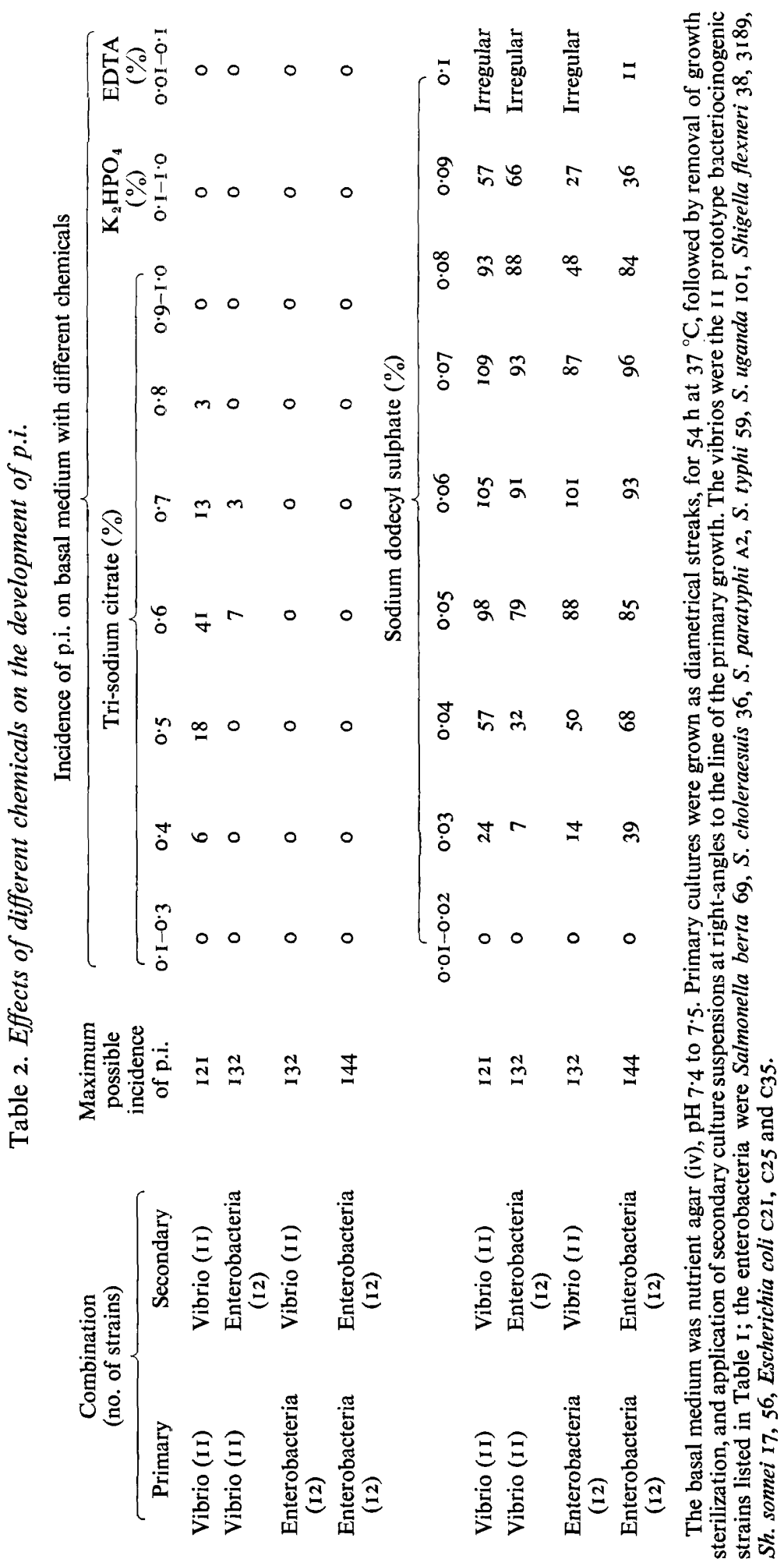




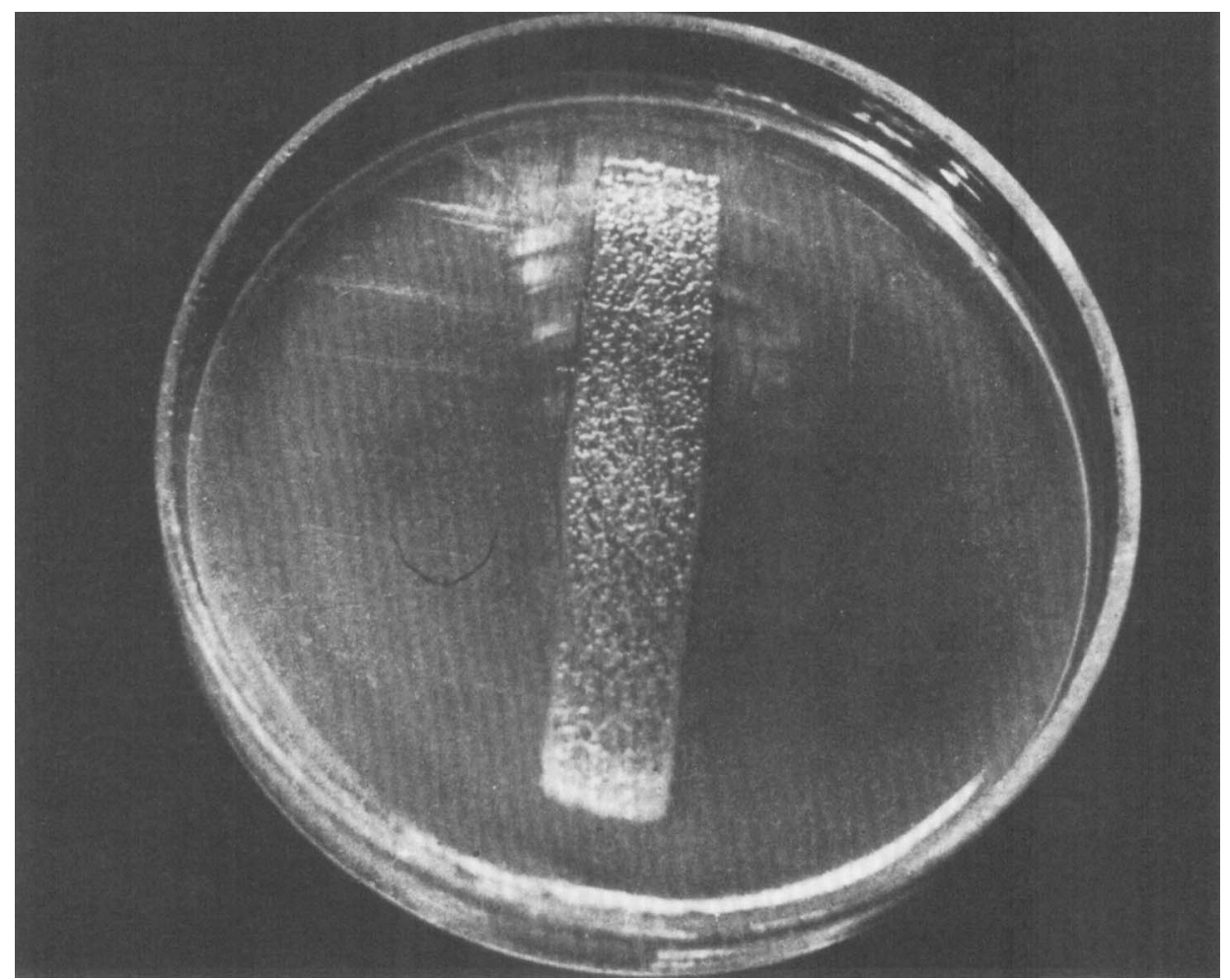

Fig. I. Paradoxical inhibition in the form of a continuous central band of growth on MPI, following growth of the primary bacteriocinogenic culture Vibrio cholerae 547; the secondary bacterium is V. cholerae 564 .

Cultures showing standard inhibition as well as p.i. against the producer culture were selected as indicators.

Tests for acquisition of bacteriocinogeny. Primary bacteriocinogenic strains were grown on appropriate medium (BTM, TSA or MPI) for $54 \mathrm{~h}$, followed by all the steps in the basic technique prior to application of the secondary non-bacteriocinogenic strains. Secondary strains were then applied by the filter-paper technique described earlier. Samples of growth were taken at 6 and $\mathrm{I} 8 \mathrm{~h}$ after application of the secondary inoculum (in triplicate from replicate plates), from the central areas overlying that of the primary bacterium and from the peripheral areas parallel to the former, by applying filter-paper strips (Whatman no. I, surface area $10 \times 40 \mathrm{~mm}^{2}$ ), for I to $2 \mathrm{~min}$. These were then removed, placed in $10 \mathrm{ml}$ peptone-water and thoroughly mixed by shaking. The samples were tested as follows: determination of total and resistant colony counts on nutrient agar and assay media containing bacteriocins of the primary strain; screening tests for acquisition of bacteriocinogeny by counting resistant colonies (at least 50, if possible) on the assay media, and determination of the inhibitory patterns of some of these bacteriocinogenic colonies. All selections were made on a random basis. Resistant colonies appearing within the zones of inhibition were counted after incubation for $\mathrm{I} 8 \mathrm{~h}$ or more for a $10 \times 40 \mathrm{~mm}^{2}$ area. Screening for detection of bacteriocinogeny among resistant colonies was done by a 'spot inoculation' technique (Fredericq, I957) on BTM or TSA, and determination of inhibitory patterns of 
bacteriocinogenic colonies was done by the method of Chakrabarty et al. (1970) for vibrios and of Abbott \& Shannon (1958) for enterobacteria. The bacteriocinogenic colonies derived from different areas of p.i. were tested for their ability to produce p.i. as primary bacteria against selected indicator strains. As controls, similar studies were performed both with non-bacteriocinogenic primary cultures as well as without any primary cultures. In the latter case an arbitrarily chosen diameter served as the central area.

Kinetic studies. The procedures are described under 'Tests for acquisition of bacteriocinogeny' in Methods, but only MPI medium was used for this test and samples were taken at $5 \mathrm{~min}$ and at $\mathrm{I}, 2,3,4,5,6$ and $\mathrm{I} 8 \mathrm{~h}$ intervals after application of the secondary inoculum. Total and bacteriocin-resistant colony counts, and screening tests for bacteriocinogeny among the latter, were done as described earlier.

Frequency tests. Frequency of acquisition of bacteriocinogeny by bacteria in the secondary inoculum was studied in two ways. The first method (in situ frequency test) was as follows. When isolated colonies (see Methods - 'Basic technique for demonstration of p.i.') were desired in the central area, dilutions of culture suspensions ranging from $\mathrm{IO}^{-3}$ to $\mathrm{IO}^{-8}$ were used; filter-paper discs corresponding to each dilution were applied in triplicate on the test and control plates (containing no growth of primary culture) of the same medium; only MPI was used. The test and control plates that yielded a large number of isolated colonies were used for colony counts and determination of recipient frequencies. As recipient colonies on test plates did not grow all over the medium, but only over a clearly demarcated area in the central region (Fig. 2), this area was measured and colonies on the control plates were counted for an equal area. The recipient frequency was calculated as follows:

Frequency of acquisition of bacteriocinogeny

$$
=\frac{(\text { No. of colonies over area } A \text { in test plates }) \times(\text { reciprocal of dilution })}{(\text { No. of colonies over area } A \text { in control plates }) \times(\text { reciprocal of dilution })}
$$

where $A$ is the area of central growth of p.i. on the test plates. The second method ("conventional' frequency test) consisted of mixing $5 \mathrm{ml}$ of a $\mathrm{I}: 10$ saline dilution of the DNA solution (described later) with an equal volume of a peptone-water dilution of an $18 \mathrm{~h}$ culture of the test bacterium containing about $10^{5}$ cells $/ \mathrm{ml}$ and incubating the mixture for I h, followed by plating out on assay media and nutrient agar for resistant and total colony counts and screening tests for bacteriocinogeny. In control experiments saline was substituted for DNA solution.

Paradoxical inhibition on cell-free surface. BTM and MPI media were used. All steps in the basic technique prior to inoculation of the secondary bacteria were followed. The medium was then detached from the Petri dish and replaced in an inverted position so that the inoculated surface was in contact with the glass. Secondary bacteria were then applied on the reverse surface, at right-angles to the line of the primary growth.

Paradoxical inhibition was also demonstrated by inoculating secondary bacteria on an agar overlay. After all the steps in the basic technique prior to inoculation of the secondary bacteria were completed, I $\mathrm{ml}$ of the corresponding medium was poured on to the plates which were then kept in the refrigerator overnight. The secondary bacteria were then inoculated in the usual manner. Samples of the central areas of growth of p.i. developing in these tests were obtained at 6 and $18 \mathrm{~h}$ respectively from MPI and BTM, and tested for bacteriocin resistance and bacteriocinogeny as described earlier.

Tests for extracellular mediator of p.i. BTM and MPI media at $\mathrm{pH} 7 \cdot 2$ were used. The primary bacteriocinogenic cultures were grown for $54 \mathrm{~h}$ at $37^{\circ} \mathrm{C}$; plates were chloroformed and aerated as already described. Gutters, $1 \mathrm{~cm}$ wide, were cut in the culture plates using a 


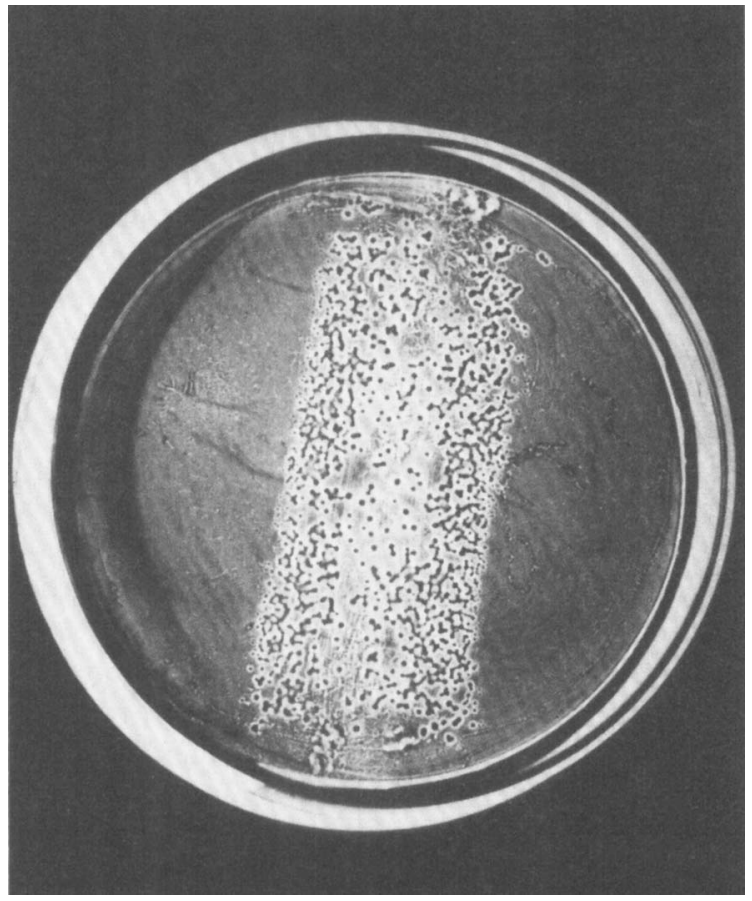

Fig. 2. Growth of bacteriocin-resistant colonies over the central area only, following application of the indicator organism Vibrio cholerae 769 by the culture-impregnated filter-paper technique. The primary bacterium producing this type of p.i. was $V$. cholerae 547 grown on MPI.

sterile scalpel. These were filled with $0.1 \mathrm{ml}$ of DNA extract prepared from the primary bacterium mixed with $\mathrm{I} \mathrm{ml}$ of corresponding medium. Plates in which gutters were filled with fresh medium only, or medium mixed with DNA extract from homologous nonbacteriocinogenic strains, as well as plates without any gutters following the removal of the primary growth and its sterilization, acted as controls. All plates were overlaid with $\mathbf{I}$ ml of the same medium and allowed to equilibrate in the refrigerator for $18 \mathrm{~h}$, and then the secondary bacteria were inoculated as described in the basic technique. To determine the DNase sensitivity of the mediator of p.i., saline dilutions of DNA preparations were treated for $3 \mathrm{~h}$ with equal volumes of DNase solution (bovine pancreatic, 'Fluca', Switzerland) at a final concentration of $0.1 \mathrm{mg} / \mathrm{ml}$ in peptone-water containing $0.0 \mathrm{I} \mathrm{mg}$ of $\mathrm{MgSO}_{4} / \mathrm{ml}$ $\mathrm{pH} \mathrm{7.2}$. The DNA-DNase mixtures were then mixed in $0.2 \mathrm{ml}$ amounts with $2 \mathrm{ml}$ of corresponding medium, and the remainder of the test was the same as in the case of DNA extract described earlier. The procedure with RNase (bovine pancreatic, British Drug Houses Ltd., India) was the same. Tests done on the central growths of p.i. were identical with those described for 'Paradoxical inhibition on cell-free surface' in Methods.

DNA extracts. Three different DNA preparations were used. The first two were based on whole cell lysates obtained by use of SDS (Fox \& Allen, 1964) and sodium deoxycholate (Jackson, I962). The other method (developed by us) consisted of adding the growth from half a plate of the test bacterium to $50 \mathrm{ml}$ of nutrient broth, followed by shaking at low speed at $37^{\circ} \mathrm{C}$ for $5 \mathrm{~h}$. SDS was then added to give a final concentration of $0.01 \%$ for vibrios and 
$0.05 \%$ for enterobacteria. No detectable lysis was observed. The suspension was then placed at $37^{\circ} \mathrm{C}$ for $2 \mathrm{~h}$, refrigerated overnight, and then centrifuged at $3000 \mathrm{~g}$ for $30 \mathrm{~min}$, passed through a millipore filter and used as a source of DNA. DNA in the extract was detected by the diphenylamine reaction (Schneider, 1957).

$S D S$ and acridine orange $(A O)$ treatment. Bacteriocinogenic enterobacteria cultures known to produce p.i. as primary bacteria, were treated with $\mathrm{AO}$ at a concentration of $25 \mu \mathrm{g} / \mathrm{ml}$ (Hirota, 1960) and plated out on nutrient agar containing AO at the same concentration. The minimum inhibitory concentration of $\mathrm{AO}$ on vibrios, and the minimum inhibitory concentrations of SDS on vibrio and enterobacteria cultures, were determined by using various concentrations of AO (e.g. 25, 12.5, 6.0 and $3 \mu \mathrm{g} / \mathrm{ml}$ ) and SDS (0.01 to $0.10 \%$ at intervals of $0.01 \%$ ) in nutrient broth. Tubes were inoculated with about 300 bacteria each, and a loopful of $18 \mathrm{~h}$ growth from the tubes containing the highest concentration of either AO or SDS was plated out on nutrient agar containing the same or different concentrations of the same chemical so as to produce numerous isolated colonies. Twentyfive colonies of a single culture from each test were tested for loss of bacteriocinogeny, by determining alterations in their inhibitory patterns as described earlier (see Methods, 'Tests for acquisition of bacteriocinogeny').

The effects of different combinations of SDS and bacteriocins on the growth of heavy (as in primary, $10^{8}$ to $10^{9}$ bacteria) and light (as in secondary, $10^{4}$ to $10^{5}$ bacteria) inocula of wild-type and recipient bacteriocinogenic vibrios and enterobacteria were studied by using MPI, BTM and TSA with or without bacteriocins. Frequencies of occurrence of bacteriocinresistant colonies among these inocula were determined at the time of application $(\mathrm{o} \mathrm{h})$ and I8 $\mathrm{h}$ after growth on MPI (see Methods, 'Assay procedures'). The culture suspensions of these bacteria were used as secondary inocula and tested against each other as primary inocula for development of p.i.

\section{RESULTS}

\section{Paradoxical inhibition on BTM and TSA}

Using Vibrio cholerae 54I as an indicator strain against 503 o-subgroup I positive and $2 \mathrm{I} 5$ O-subgroup I negative vibrio cultures, and $V$. cholerae 852,540 , NIH35A3, 569B and 564 against the II prototype bacteriocinogenic vibrios (Chakrabarty et al. 1970), the incidences of p.i. on BTM were I68 and 9I, and o, 3, 2, 3 and 5, respectively. TSA did not support development of p.i. for vibrios. Forty-eight bacteriocinogenic enterobacteria cultures (Table I) tested on BTM and TSA with a selected set of indicator bacteria (see Table 6 below) did not show p.i.

\section{Effects of various factors on the development of paradoxical inhibition}

SDS, at concentrations of 0.03 to $0.09 \%$ at a $\mathrm{pH}$ of 7.5 to 7.6 for vibrios and 7.0 to 7.5 for enterobacteria, promoted p.i. EDTA alone did not have any role, but could enhance the action of SDS over a range of 0.01 to $0.03 \%$ (Table 2). All the four basic media were able to support p.i.

\section{Relationship of bacteriocin types with development of paradoxical inhibition}

When the I I prototype bacteriocinogenic strains of Vibrio cholerae (see Table I) grown on MPI were tested against each other and against 12 enterobacteria as indicator bacteria, p.i. was observed among all the pairs of vibrios (including homologous ones) on at least one of the three incubation schedules of the primary inocula, namely 44,54 and $64 \mathrm{~h}$. Certain strains used as indicators, e.g. Vibrio cholerae 540, 564, 14033, NIH35A3 and 569B, 
Table 3. Frequency of p.i. among different genera of Enterobacteria, Vibrio and Alcaligenes on MPI

\begin{tabular}{|c|c|c|c|c|c|c|c|}
\hline \multirow[b]{2}{*}{$\begin{array}{l}\text { Primary } \\
\text { culture } \\
\text { (no.) }\end{array}$} & \multirow[b]{2}{*}{$\begin{array}{l}\text { Paradoxical } \\
\text { inhibition }\end{array}$} & \multicolumn{6}{|c|}{ Secondary culture (no.) } \\
\hline & & $\begin{array}{l}\text { Vibrio } \\
\text { cholerae } \\
\text { (I I) }\end{array}$ & $\begin{array}{l}\text { Salmonella } \\
\text { (I5) }\end{array}$ & $\begin{array}{l}\text { Shigella } \\
(8)\end{array}$ & $\begin{array}{c}\text { Escherichia } \\
\text { coli } \\
\text { (10) }\end{array}$ & $\begin{array}{l}\text { Proteus } \\
\text { mirabilis } \\
\quad(25)\end{array}$ & $\begin{array}{l}\text { Alcaligenes } \\
\text { (4) }\end{array}$ \\
\hline \multirow{3}{*}{$\begin{array}{l}\text { Vibrio } \\
\quad \text { cholerae } \\
\text { (I I) }\end{array}$} & Positive & 102 & 117 & 55 & 58 & 176 & 27 \\
\hline & $\underset{\text { possible }}{\text { Maximum }}$ & 121 & 165 & 88 & I IO & 275 & 44 \\
\hline & $\begin{array}{l}\text { Frequency } \\
(\%)\end{array}$ & $84 \cdot 3$ & $70 \cdot 9$ & $62 \cdot 5$ & $52 \cdot 7$ & 64 & $6 I \cdot 4$ \\
\hline \multirow{3}{*}{$\begin{array}{l}\text { Salmonella } \\
\quad \text { (I 5) }\end{array}$} & Positive & 130 & 82 & 74 & 96 & 225 & 35 \\
\hline & $\begin{array}{c}\text { Maximum } \\
\text { possible }\end{array}$ & 165 & 225 & 120 & 150 & 375 & 60 \\
\hline & $\begin{array}{l}\text { Frequency } \\
(\%)\end{array}$ & $78 \cdot 8$ & $80 \cdot 98$ & $6 \mathrm{I} \cdot 7$ & 64 & 60 & $58 \cdot 3$ \\
\hline \multirow[t]{3}{*}{ Shigella (8) } & Positive & 60 & 65 & 50 & 40 & 104 & Io \\
\hline & $\begin{array}{r}\text { Maximum } \\
\text { possible }\end{array}$ & 88 & 120 & 64 & 80 & 200 & 32 \\
\hline & $\begin{array}{c}\text { Frequency } \\
(\%)\end{array}$ & $68 \cdot 2$ & $54 \cdot 2$ & $78 \cdot 1$ & 50 & 52 & $3 I \cdot 3$ \\
\hline \multirow{3}{*}{$\begin{array}{c}\text { Escherichia } \\
\text { coli (10) }\end{array}$} & Positive & 69 & 93 & 33 & 72 & 153 & 17 \\
\hline & $\begin{array}{c}\text { Maximum } \\
\text { possible }\end{array}$ & IIO & 150 & 80 & 100 & 250 & 40 \\
\hline & $\begin{array}{l}\text { Frequency } \\
(\%)\end{array}$ & $62 \cdot 7$ & 62 & $4 I \cdot 3$ & 72 & 68 & $40 \cdot 5$ \\
\hline \multirow{3}{*}{$\begin{array}{l}\text { Alcaligenes } \\
\text { (4) }\end{array}$} & Positive & $2 I$ & I 8 & I I & 15 & 30 & I I \\
\hline & $\begin{array}{c}\text { Maximum } \\
\text { possible }\end{array}$ & 44 & 60 & 32 & 40 & 100 & 16 \\
\hline & $\begin{array}{l}\text { Frequency } \\
(\%)\end{array}$ & $47 \cdot 7$ & 30 & $34 \cdot 4$ & $37 \cdot 5$ & 30 & $68 \cdot 8$ \\
\hline
\end{tabular}

Vibrios tested were the I I prototype strains listed in Table I; other bacteria are also listed in Table I.

exhibited a higher frequency compared with the others. All the indicator enterobacteria exhibited p.i. with at least one of the prototype bacteriocinogenic $V$. cholerae strains.

Intrageneric and cross-generic p.i.

The frequency of p.i. was highest among vibrios. It also occurred at high frequencies among members of Salmonella, Shigella, Escherichia coli and Proteus groups, and between these and members of genera Vibrio and Alcaligenes (Table 3). Only bacteriocinogenic bacteria used as primary inocula could produce p.i. with secondary bacteriocinogenic and non-bacteriocinogenic bacteria.

Central growths of p.i., identified as described in Table $\mathrm{I}$, were found to belong to the secondary cultures. Tests in which secondary inoculations were omitted, or done as parallel streaks leaving areas of uninoculated media, did not yield any growth anywhere in the medium in the case of the former or in the uninoculated zones in the case of the latter, even after prolonged incubation. 


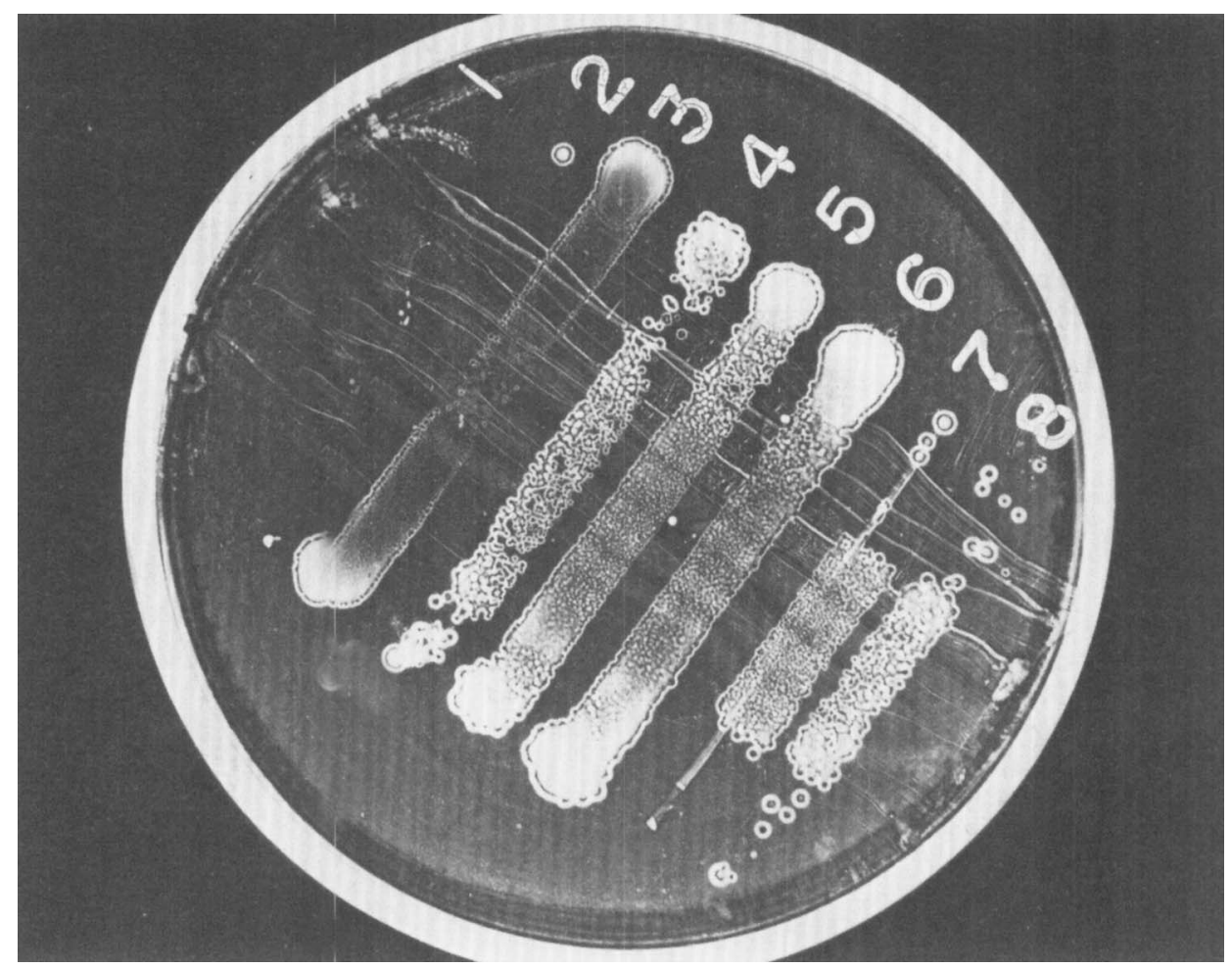

Fig. 3. The inhibition pattern of Vibrio cholerae $\mathrm{KII}$ on BTM. The indicator strains in the order I to 8, are: Shigella flexneri 3189 and 30225, Salmonella typhi 59, and V. cholerae 54I, 547, I4033, 540 and 564. Strains $I$ and 2 show total inhibition and 3 shows a narrow inhibition zone; 4 shows all the three morphological components of p.i., although these are not very well demarcated from each other. Strains 5 and 6, which might otherwise appear to be resistant, show clear tendencies for 'breaking up' the growth at points correspondi ng to the zones of inhibition (cf. 7 and 8 of this Figure); 7 and 8 show well demarcated areas of central growth with only a few colonies within the zones of inhibition and have scanty peripheral growths.

\section{Morphology of paradoxical inhibition on BTM and MPI}

Paradoxical inhibition exhibited by vibrio indicator cultures on BTM had three distinct components (Fig. 3): a central band of growth which often extended beyond the margins of the primary growth, an intervening zone of inhibition, and peripheral growths. Those inhibition zones which contained a large number of colonies made the boundaries of the central growth and its demarcation from the peripheral growths somewhat indistinct, and with wide inhibition zones the presence of peripheral growth depended on the length of the secondary inoculum. On MPI, the majority of the indicator cultures developed only the central growth of p.i., but with some cultures, all three components developed distinctly (Fig. 4). The central growth either extended beyond or remained confined within the boundaries of the primary growth, and varied from plentiful to scanty. Studies on indicator strains of Vibrio cholerae NIH35A3, 540, 547, 564, 569B and 1352 against the I I prototype bacteriocinogenic vibrios incubated for 44,54 and $64 \mathrm{~h}$, showed that with respect to any reacting pair the size of the central growth was widest with $44 \mathrm{~h}$ and narrowest with $64 \mathrm{~h}$ primary incubation. Using prototype strain $V$. cholerae KI I and an incubation period of 


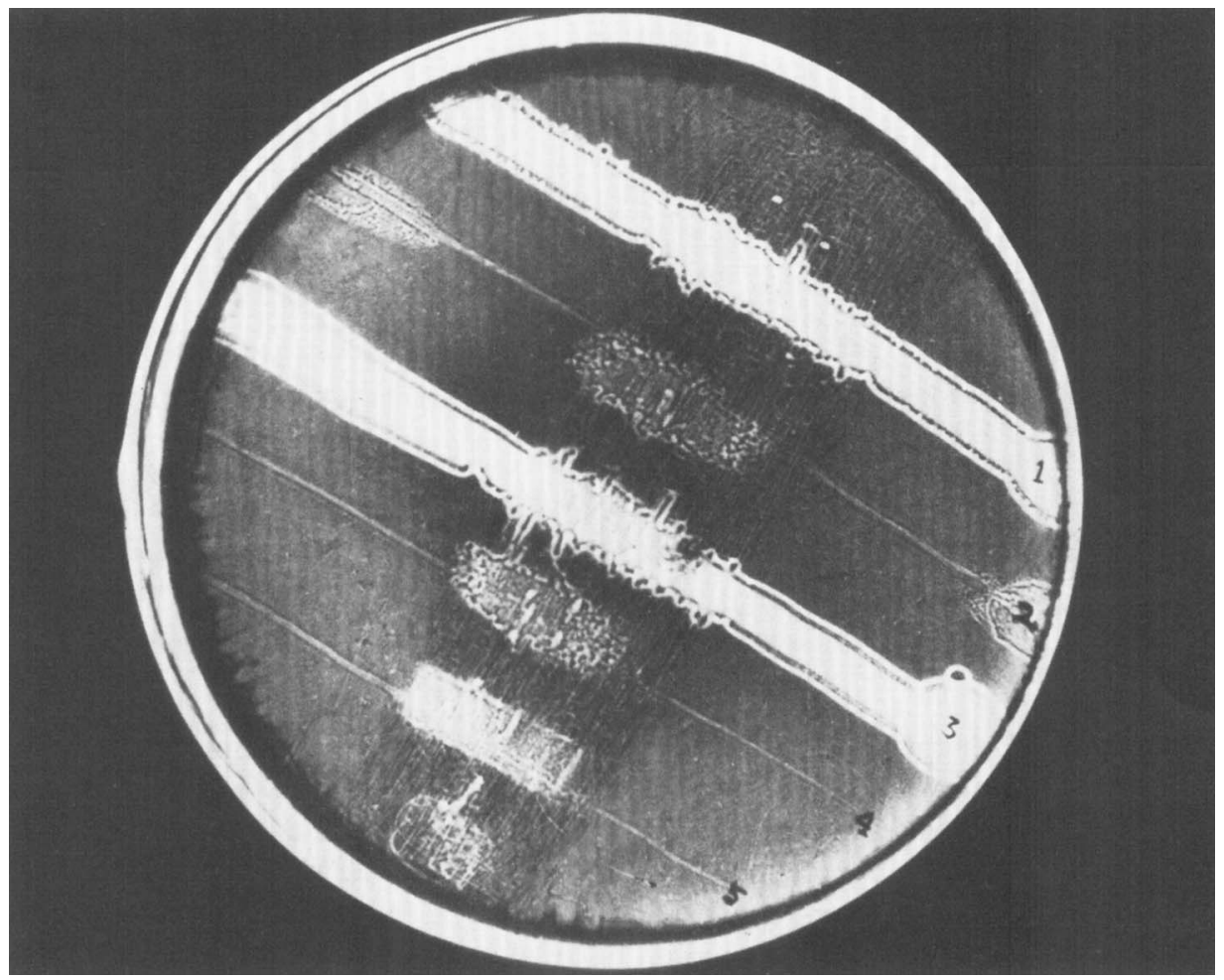

Fig. 4. Paradoxical inhibition produced by Vibrio cholerae 14033 on MPI. The secondary cultures, in the order I to 5 , are: $V$. cholerae 547 , Salmonella typhi 59, V. cholerae $1352, S$. paratyphi A2, and $V$. cholerae 540. Strains $I$ and 3 are apparently resistant, although the tendency of the central growths of these strains to separate out could be clearly observed. Strain 2 exhibits p.i. in its typical form; others have only central growths and the zones of inhibition extend far outwards. The growth present at the bottom of the medium is the remainder of the primary culture.

$54 \mathrm{~h}$, the indicators could be arranged in the order of their decreasing widths of central growth as follows: $V$. cholerae $\mathrm{I} 352,547,569 \mathrm{~B}, \mathrm{NIH} 35^{\mathrm{A}} 3,564$ and 540.

\section{Assay of bacteriocin activity}

While the bacteriocin titres in different zones on MPI, in the central zones on different media, and in all the zones on BTM and TSA subjected to longer primary incubation, tended to be similar and comparatively higher than for those incubated for shorter periods, in the latter, the titres on BTM and TSA in the central zones were higher than the corresponding zones of inhibition (Table 4); replicate plates used as control showed p.i. with some of the indicators used for assay.

Acquisition of bacteriocinogeny by bacteria in the different components of p.i.

Except for Shigella flexneri $3 \mathrm{I} 89$, which gave a standard inhibition with a few colonies situated peripherally on TSA, p.i. developed in all other tests. The frequencies of bacteriocinresistant cells among the populations of secondary (non-bacteriocinogenic) cultures in different components of p.i. are given in Table 5. Screening tests for bacteriocinogeny of 
Table 4. Bacteriocin titres in different zones of BTM, TSA and MPI

\begin{tabular}{|c|c|c|c|c|c|c|c|c|}
\hline \multirow{2}{*}{\multicolumn{2}{|c|}{$\begin{array}{c}\text { Bacteriocinogenic } \\
\text { primary strain }\end{array}$}} & \multirow{3}{*}{$\begin{array}{l}\text { Indicator } \\
\text { strain }\end{array}$} & \multicolumn{5}{|c|}{ Bacteriocin titres* } & \\
\hline & & & \multicolumn{3}{|c|}{ BTM/TSA $\uparrow$} & \multicolumn{3}{|c|}{ MPI } \\
\hline Description & Test condition & & $\mathrm{CZ}$ & IZ & $\mathbf{P Z}$ & $\mathrm{CZ}$ & IZ & PZ \\
\hline \multirow[t]{2}{*}{$\begin{array}{l}\text { Vibrio cholerae } \\
\quad 547\end{array}$} & $\begin{array}{l}54 \mathrm{~h} \text { incubation } \\
\text { and } \mathrm{r} 8 \mathrm{~h} \text { at } 4{ }^{\circ} \mathrm{C}\end{array}$ & $\begin{array}{l}\text { Vibrio cholerae } 769 \ddagger \\
\text { Shigella flexneri } 3189\end{array}$ & $\begin{array}{l}16 \\
32\end{array}$ & $\begin{array}{l}4 \\
4\end{array}$ & $\begin{array}{l}\circ \\
0\end{array}$ & $\begin{array}{l}16 \\
16\end{array}$ & $\begin{array}{l}16 \\
16\end{array}$ & $\begin{array}{r}16 \\
8\end{array}$ \\
\hline & $\begin{array}{l}72 \mathrm{~h} \text { incubation } \\
\text { and } 48 \mathrm{~h} \text { at } 4{ }^{\circ} \mathrm{C}\end{array}$ & $\begin{array}{l}\text { Vibrio cholerae } 769 \\
\text { Shigella flexneri } 3 \text { I } 89\end{array}$ & $\begin{array}{l}32 \\
64\end{array}$ & $\begin{array}{l}32 \\
64\end{array}$ & $\begin{array}{l}32 \\
64\end{array}$ & $\begin{array}{l}32 \\
64\end{array}$ & $\begin{array}{l}32 \\
64\end{array}$ & $\begin{array}{l}16 \\
32\end{array}$ \\
\hline \multirow[t]{2}{*}{$\begin{array}{l}\text { Escherichia coli } \\
\text { C25 }\end{array}$} & $\begin{array}{l}54 \mathrm{~h} \text { incubation } \\
\text { and } 18 \mathrm{~h} \text { at } 4{ }^{\circ} \mathrm{C}\end{array}$ & $\begin{array}{l}\text { Shigella flexneri } 3189 \ddagger \\
\text { Escherichia coli Row }\end{array}$ & $\begin{array}{l}32 \\
32\end{array}$ & $\begin{array}{l}8 \\
4\end{array}$ & $\begin{array}{l}2 \\
0\end{array}$ & $\begin{array}{l}32 \\
32\end{array}$ & $\begin{array}{l}32 \\
16\end{array}$ & $\begin{array}{r}16 \\
8\end{array}$ \\
\hline & $\begin{array}{l}72 \mathrm{~h} \text { incubation } \\
\text { and } 48 \mathrm{~h} \text { at } 4{ }^{\circ} \mathrm{C}\end{array}$ & $\begin{array}{l}\text { Shigella flexneri } 3189 \\
\text { Escherichia coli Row }\end{array}$ & $\begin{array}{l}32 \\
32\end{array}$ & $\begin{array}{l}32 \\
32\end{array}$ & $\begin{array}{l}32 \\
32\end{array}$ & $\begin{array}{l}64 \\
64\end{array}$ & $\begin{array}{l}32 \\
32\end{array}$ & $\begin{array}{l}32 \\
16\end{array}$ \\
\hline
\end{tabular}

resistant colonies belonging to different areas of p.i. and selected at random were performed by using indicator bacteria: Shigella flexneri 3189 and Vibrio cholerae 852 for vibrios, and Sh. flexneri 3189 and $S h$. sonnei M56 for enterobacteria. The results showed that only those colonies originating from the central area of both MPI and BTM had acquired bacteriocinogeny (and not all of these were bacteriocinogenic). The bacteriocinogenic character of colonies was stable when subcultured on nutrient agar and all those tested were able to produce p.i. as primary bacteria on MPI with at least one member of the set of secondary bacteria: V. cholerae 564, 540 and 769, Sh. sonnei 56 and Sh. flexneri 3189 . The inhibitory patterns of some randomly selected bacteriocinogenic vibrio and enterobacteria colonies are given in Table 6. Control experiments were made with non-bacteriocinogenic bacteria, using V. cholerae 769 and 540 and Sh. flexneri 3189, and Escherichia coli Row as primary and $V$. cholerae 769 and Sh. flexneri 3189 as secondary bacteria for the vibrio and enterobacteria strains respectively. The samples were assayed on BTM or TSA containing bacteriocins of $V$. cholerae 547 or $E$. coli $\mathrm{C} 25$ as in the test proper. The results showed that neither p.i. nor standard inhibition developed between any of the reacting pairs of organisms; the frequency of occurrence of resistant colonies among samples derived from different media and tested on assay media varied between $10^{-6}$ and $10^{-7} \%$; none of the resistant colonies were bacteriocinogenic.

\section{Kinetics of acquisition and loss of bacteriocinogeny}

Bacteriocinogenic strain Vibrio cholerae 547 was used as the primary and V. cholerae 769 as the secondary inoculum. The results showed that the frequency of occurrence of resistant colonies and acquisition of the bacteriocin markers increased rapidly in the initial stages, reaching a peak by about $4 \mathrm{~h}$; thereafter, there was a decline and, after $\mathrm{I} 8 \mathrm{~h}$, the frequency was very low (Table 7 ).

\section{Frequency of acquisition of bacteriocin factors}

Using Vibrio cholerae 547 as primary and V. cholerae 675 and 769 and Shigella flexneri $3 \mathrm{I} 89$ as secondary bacteria, the frequencies of acquisition of bacteriocinogeny obtained with in situ frequency tests were $1.8 \times 10^{-3}, 7.3 \times 10^{-2}$ and $6.9 \times 10^{-3}$ respectively; using 
Paradoxical inhibition

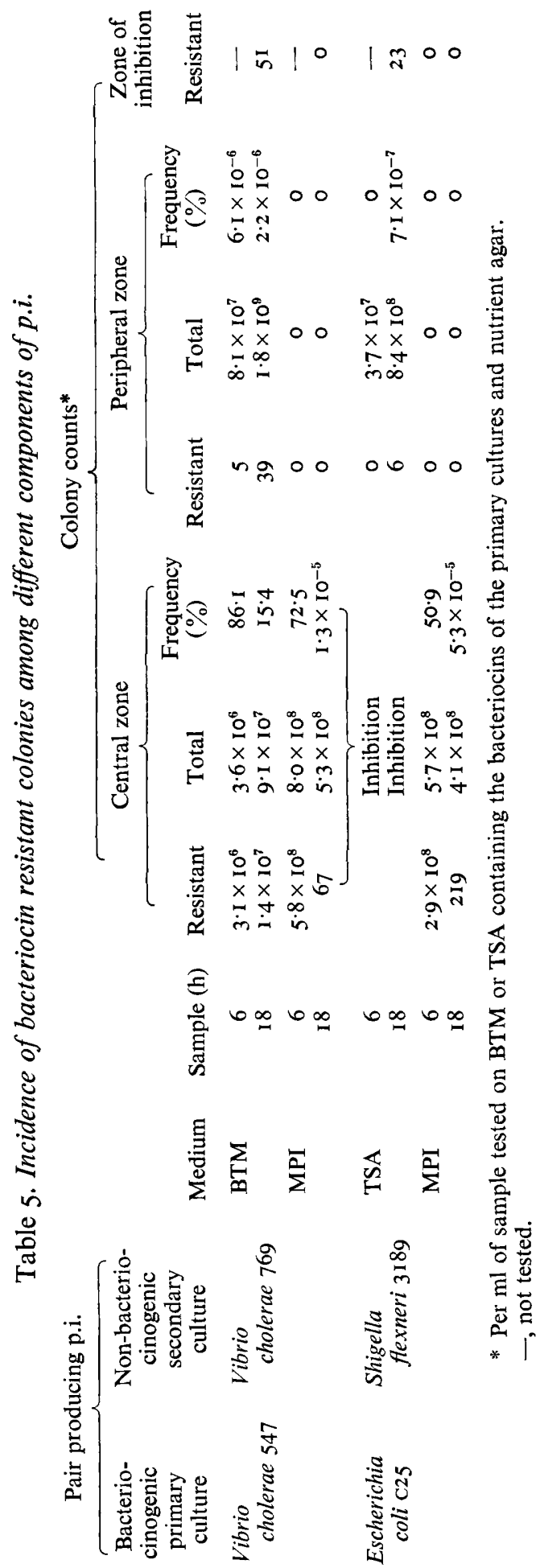




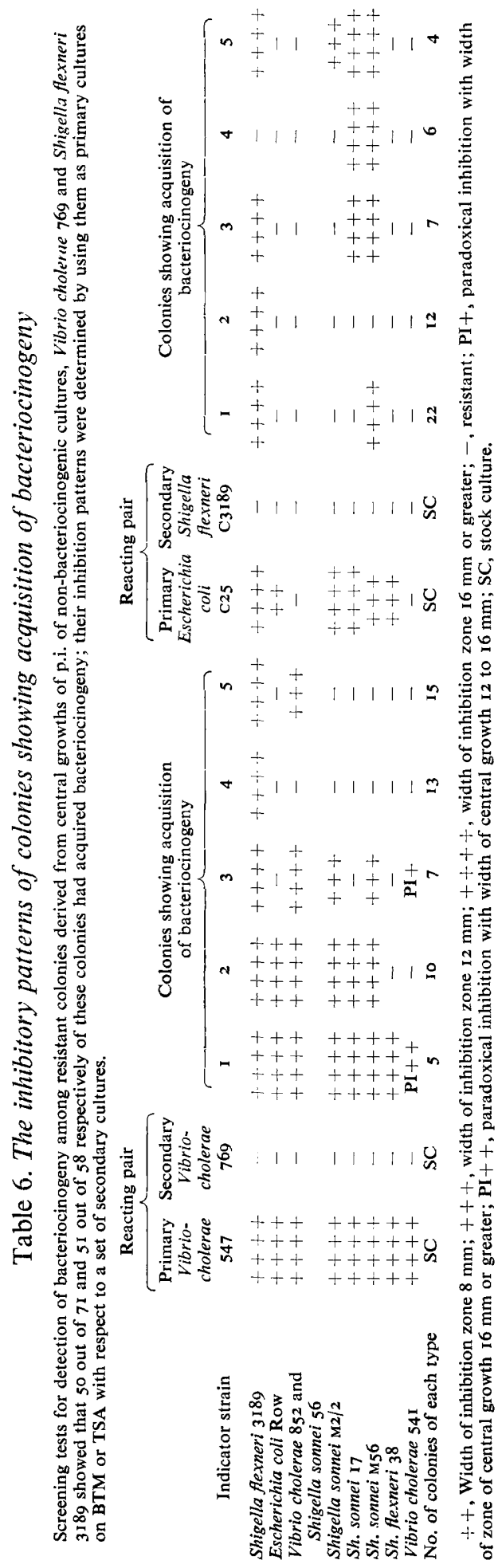


Table 7. Kinetics of acquisition and loss of bacteriocinogeny among recipient populations

Primary and secondary cultures were Vibrio cholerae 547 and 769 respectively.

\begin{tabular}{|c|c|c|c|c|c|c|}
\hline \multirow{2}{*}{$\begin{array}{c}\text { Time of } \\
\text { sampling (after } \\
\text { inoculation) }\end{array}$} & \multicolumn{3}{|c|}{ Colony counts* } & \multicolumn{3}{|c|}{ No. of resistant colonies } \\
\hline & Total & Resistant & $\begin{array}{c}\text { Frequency } \\
(\%)\end{array}$ & Tested & $\begin{array}{l}\text { Bacterio- } \\
\text { cinogenic }\end{array}$ & $\begin{array}{l}\text { Frequency } \\
\qquad(\%)\end{array}$ \\
\hline $5 \mathrm{~min}$ & $2.5 \times 10^{5}$ & $\mathrm{I} \cdot \mathrm{I} \times 1 \mathrm{IO}^{4}$ & $4 \cdot 4$ & 50 & 48 & $96 \cdot 0$ \\
\hline I h & $5.7 \times 10^{5}$ & $3.0 \times 10^{5}$ & $52 \cdot 6$ & 50 & 46 & $92 \cdot 0$ \\
\hline $2 \mathrm{~h}$ & $18.6 \times 10^{5}$ & $12.6 \times 10^{5}$ & $67 \cdot 7$ & 50 & 43 & $86 \cdot 0$ \\
\hline $3 \mathrm{~h}$ & $7 \cdot 2 \times 10^{6}$ & $5.7 \times 10^{6}$ & $79 \cdot 2$ & 50 & 43 & $86 \cdot 0$ \\
\hline $4 h$ & $3.1 \times 10^{7}$ & $3.0 \times 10^{7}$ & $96 \cdot 8$ & 47 & 45 & $95 \cdot 7$ \\
\hline $5 \mathrm{~h}$ & $1 \cdot 0 \times 10^{8}$ & $8.5 \times 10^{7}$ & $85 \cdot 0$ & 49 & 40 & $8 I \cdot 6$ \\
\hline $6 \mathrm{~h}$ & $8.0 \times 10^{8}$ & $5.8 \times 10^{8}$ & $72 \cdot 5$ & 50 & 35 & $70 \cdot 0$ \\
\hline I $8 \mathrm{~h}$ & $5.3 \times 10^{8}$ & 67 & $1 \cdot 3 \times 10^{-5}$ & 50 & 23 & $46 \cdot 0$ \\
\hline
\end{tabular}

Escherichia coli $\mathrm{C} 25$ as primary and Sh. flexneri 3189 as secondary bacteria, the frequency was $2 \cdot \mathrm{I} \times 1 \mathrm{I}^{-2}$. The 'conventional' frequency tests using DNA preparation from $V$. cholerae 547 gave frequencies for $V$. cholerae 769 and Sh. flexneri 3189 of $\mathrm{I} \cdot \mathrm{I} \times \mathrm{IO}^{-2}$ and $3.5 \times 1 \mathrm{I}^{-4}$ respectively; the control tests did not yield any growth on assay media. The resistant colonies had acquired bacteriocinogeny at very high frequencies.

\section{Paradoxical inhibition on cell-free surface}

To demonstrate the extracellular nature of the agents responsible for p.i., the I I prototype strains of Vibrio cholerae (Table I) and Io enterobacteria were inoculated as primary bacteriocinogenic cultures on MPI, BTM being used in addition for vibrios. Inoculation of indicator bacteria on the reverse surface of media yielded p.i. on both the media. All the primary bacteria produced this reaction with different indicator bacteria; the incidence varied from one up to five, and was similar to that on the control plates where primary and secondary inoculations were on the same surface (Fig. 5). Inoculations of secondary bacteria on agar overlay gave the same results as control plates minus agar overlay. Colonies from the central areas of p.i. produced by indicator bacteria $V$. cholerae 769 and Shigella flexneri 3I 89 acquired bacteriocinogenic characters.

\section{Paradoxical inhibition with DNA extracts}

DNA extracts were prepared from bacteriocinogenic Vibrio cholerae strains 547, I4033 and 7698 (a bacteriocinogenic derivative of $V$. cholerae 769), non-bacteriocinogenic $V$. cholerae 769, Shigella flexneri 3 I89в (a bacteriocinogenic derivative of Sh. flexneri 3 I89) and Sh. flexneri 3I89. All three types of DNA extracts (see Methods) were prepared from the vibrios and were used on both BTM and MPI; for enterobacteria, the deoxycholate-lysed preparation was omitted and only MPI was used. The indicator bacteria used were the same as in the preceding test. The results showed that incorporation of DNA from the bacteriocinogenic strains into the gutters followed by inoculation of indicator bacteria, resulted in the development of p.i. which was similar to that on the control plates with corresponding primary culture prepared according to the 'Basic technique for demonstration of p.i.' (see Methods). Furthermore, colonies derived from the central growths of p.i. of nonbacteriocinogenic indicator bacteria, V. cholerae 769 and $S h$. flexneri 3I89, were found to 


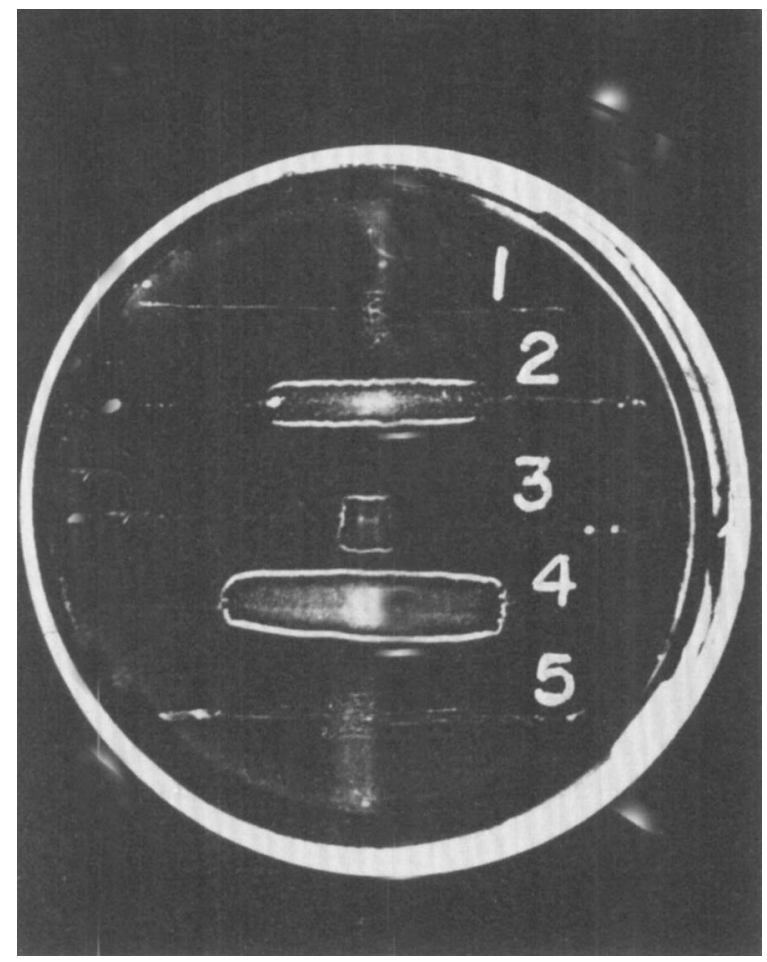

Fig. 5. Paradoxical inhibition on cell-free (reverse) surface. The primary culture was Vibrio cholerae KI I grown on MPI and the secondary cultures, in the order I to 5, were $V$. cholerae 540, 547, NIH35A3, I352 and 564. Strains I, 3 and 5 show central growths located opposite the site of the primary culture (indicated as a faint haze) which are more or less confined within the boundaries of the latter; 2 and 4 have central growths which extend considerably beyond this area. The inhibition zones are extensive and peripheral growths are absent (cf. 4 and 5 of Fig. 4).

have acquired bacteriocinogeny. Vibrio cholerae 769, Sh. flexneri 3189 and their respective DNA extracts all failed to produce any p.i., as also did media minus extracts.

\section{DNase and RNase sensitivity of DNA extracts}

DNase treatment of DNA preparations from whole-cell lysates of the above bacteriocinogenic strains prior to incorporation into gutters, resulted in no visible p.i. Standard inhibition only was shown with some indicator bacteria; while the reactions of other indicator bacteria remained unchanged from those in the untreated controls. Similar tests with DNA prepared by the method described in Methods abolished p.i. for all the indicator bacteria. RNase treatment of the DNA preparations was without effect.

\section{Effects of $A O$ and SDS on bacteriocinogeny}

All the enterobacteria strains tested grew in the presence of AO and SDS at concentrations $25 \mu \mathrm{g} / \mathrm{ml}$ and $0 . \mathrm{I} \%$ respectively. The minimum inhibitory concentrations of these substances for vibrios were $6 \mu \mathrm{g} / \mathrm{ml}$ for AO and $0.03 \%$ for SDS in nutrient broth, and the same concentration of AO and $0 . \mathrm{I} \%$ of SDS on nutrient agar medium. The 'curing' effects of these substances on the bacteriocinogenic vibrios and enterobacterial cultures are shown in Table 8 . The colonies derived from different cultures that had become non-bacteriocinogenic 
Table 8. Effects of $A O$ and SDS on bacteriocinogeny

The test strains were initially grown in fluid media followed by plating out on solid media containing either AO or SDS; 25 isolated colonies of each strain were tested. The vibrios were grown in AO at $3 \mu \mathrm{g} / \mathrm{ml}$ concentration in both the fluid and solid media and at 0.02 and $0.09 \%$ concentrations of SDS respectively on these two media. The enterobacteria were grown in AO and SDS at concentrations of $25 \mu \mathrm{g} / \mathrm{ml}$ and $0.1 \%$ respectively on fluid and solid media.

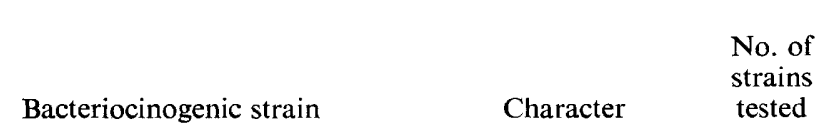

Wild type 5

Vibrio cholerae KI I, 547, 847, I4033, NIH35A3

Vibrio cholerae $675 \mathrm{~B}, 769 \mathrm{~B}$

Salmonella chester $17, S$. choleraesuis 37 ,

S. essen 22, S. paratyphi A2, S. typhi 59

Shigella flexneri 38 , Sh. sonnei 56

Shigella flexneri $3 \mathrm{I} 89 \mathrm{~B}, 30225 \mathrm{~B}$

Escherichia coli $\mathrm{C25}, \mathrm{C} 35$

Escherichia coli Row B
No. of strains showing 'curing'*

$\begin{array}{cc}\text { AO } & \text { SDS } \\ 0 & 5 \\ 0 & 2 \\ \text { I } & 4 \\ \text { I } & 2 \\ \text { I } & 2 \\ \text { I } \dagger & 2 \\ \text { I } & \text { I }\end{array}$

* Loss of markers in all the 25 colonies tested.

$\uparrow$ Partial loss of inhibitory pattern.

Table 9. Effects of SDS and bacteriocins on the growths of bacteriocinogenic bacteria

Vibrio cholerae KII, 547 and 769B (recipient of bacteriocinogeny) were tested on MPI and BTM, and Escherichia coli $\mathrm{C} 25$, Shigella sonnei $\mathrm{M} 2 / 2$ and Sh. flexneri $3189 \mathrm{~B}$ (recipient of bacteriocinogeny) were tested on MPI and TSA with or without bacteriocins; presence of bacteriocin in the medium was ensured by growth of the bacteriocinogenic cultures for $54 \mathrm{~h}$ at $37^{\circ} \mathrm{C}$. A heavy inoculum consisted of $10^{8}$ to $10^{9}$ cells (fresh culture from nutrient agar) and a light inoculum contained $10^{4}$ to $10^{5}$ cells (I loopful of $18 \mathrm{~h}$ peptone-water culture).

Conditions

Growth on media containing SDS

Growth on media without SDS

Reactions of secondary culture suspension, when used against primary growths on MPI resulting from heavy and light inocula

Frequency of occurrence of resistant cells on MPI containing homologous bacteriocin
Bacteriocinogenic cultures

$\begin{array}{cc}\overbrace{\text { Heavy }}^{\text {Hoculum }} & \begin{array}{c}\text { Light } \\ \text { inoculum }\end{array} \\ + & - \\ + & + \\ + & +* \\ + & + \\ \text { p.i. } & \text { Resistant } \\ \text { p.i.t } & \text { Resistant }\end{array}$

MPI with homologous bacteriocin

MPI without bacteriocin

BTM with homologous bacteriocin

TSA with homologous bacteriocin

Homologous suspension

Heterologous suspension

At $18 h$
$43-78 \%$

$\circ$

* Only Vibrio cholerae 769 в produced p.i.

$\uparrow$ Only $V$. cholerae 547 was sensitive.

+ Only $V$. cholerae KI I and Escherichia coli C25 were resistant.

+ , Growth; -, no growth; \pm , markedly reduced growth. 
failed to produce p.i. on MPI when tested as primary cultures, but their untreated homologous cultures did.

The behaviour of heavy and light inocula of different bacteriocinogenic strains on media containing different combinations of SDS and bacteriocin appeared to be distinctly different. Their behaviour also differed with respect to the reactions of homologous and heterologous secondary culture suspensions used against the two types of primary inocula (Table 9).

\section{DISCUSSION}

The central growth of sensitive bacteria within the zone of inhibition may be considered to be due either to inactivation of the bacteriocins by the proteolytic enzymes of the producer strain or to their adsorption and removal by the latter (Wahba, I963; Nomura, 1967). It has been postulated that the use of inhibitors of proteolytic enzymes, e.g. sodium citrate, $\mathrm{K}_{2} \mathrm{HPO}_{4}$ and iodo-acetic acid, would prevent central growth (Wahba, 1963).

Our findings do not support these hypotheses. The typing media for Pseudomonas aeruginosa (Darrell \& Wahba, 1964; Zabransky \& Day, 1969) and BTM (Chakrabarty et al. 1970) contain adequate concentrations of these inhibitory chemicals yet consistently support the development of p.i. Even if inactivation or adsorption processes produced 'bacteriocindeficient' central zones, prolonged refrigeration and sterilization of media after the removal of the primary culture should result in rediffusion of the bacteriocins and equilibration of their concentrations between the central and inhibition zones. Development of p.i., under these circumstances, both on the usual and cell-free surfaces casts doubt on such a possibility. Our findings on the bacteriocin concentrations in the different zones of BTM, TSA and MPI do not suggest that 'bacteriocin-deficient' central zones exist (Table 4).

Bacteriocin resistance in the secondary inoculum was indicated in two ways: by welldefined growth in the centre of the zone of inhibition, and by the presence of resistant colonies in other areas of p.i. Studies on the latter showed that they occurred on BTM and TSA in small numbers, but were rarely present on MPI. Resistant colonies occurred at very low levels in peripheral growths sampled from BTM, TSA and MPI (Table 5). None of these colonies acquired bacteriocinogeny when derived from non-bacteriocinogenic stocks, irrespective of the media of their isolation. These were, therefore, considered to be resistant mutants selected by the action of the bacteriocins.

The colonies from the central area of p.i. on BTM and MPI exhibited both bacteriocin resistance and bacteriocinogeny at high frequencies (Tables 5 and 6). The conditions for acquisition of these characteristics were clearly definable. The presence of bacteriocins was essential but not wholly sufficient since p.i. and acquisition of bacteriocinogeny occurred on MPI but not on TSA, although both media supported bacteriocin production by the enterobacteria. Paradoxical inhibition and bacteriocinogeny occurred when the primary bacteria was bacteriocinogenic and the secondary inoculum was placed on the same or the reverse surface, or when, along with the underlying medium, it was removed and replaced with fresh medium containing DNA extract from the homologous primary bacterium. Paradoxical inhibition and acquired bacteriocinogeny did not occur when the primary bacterium was non-bacteriocinogenic (irrespective of the surface of the medium on which it was inoculated), when there was no primary growth, when the DNA extract came from a nonbacteriocinogenic bacterium, or when the DNA extract was omitted. Furthermore, colonies of non-bacteriocinogenic populations that had acquired bacteriocinogeny, could produce p.i. on appropriate media and act as primary bacteria for the acquisition of bacteriocinogeny 
by other secondary bacteria. The process of acquisition, its overall frequency and loss had also several distinctive characteristics.

A mutational basis for such changes is unlikely. Bacteriocinogeny is not known to be acquired through mutations (Hayes, I968) and the characteristics of the acquisition process described here do not suggest it. However, if the resistant bacteriocinogenic colonies constituting the abundant central growth are considered to be mutants or products of immunitybreakdown mechanism and lethal biosynthesis (Nomura, 1967), their particular predilection for the central area which had comparatively higher bacteriocin concentration is not explained. Tri-sodium citrate, $\mathrm{K}_{2} \mathrm{HPO}_{4}$ and iodo-acetic acid present in BTM are not known to be mutagenic (Hayes, I968); nor is SDS, present in MPI (Tomoeda, Inuzuka, Kubo \& Nakamura, 1968; Salisbury, Hedges \& Datta, 1972; Sonstein \& Baldwin, 1972). Furthermore, if these substances possess a mutagenic or inducer role, it should not be restricted to the central zone. Paradoxical inhibition and acquired bacteriocinogeny noted in the presence of SDS (on MPI) also occurred in its absence (on BTM).

The development of p.i. on the usual and cell-free surfaces suggests that the transfer does not require cell contact. Conjugation as the possible genetic process can therefore be excluded. Genetic transfer by a transducing phage from the primary bacteria seems unlikely because it would have to diffuse through a layer of agar to the reverse surface. Moreover, prolonged exposure to chloroform would probably kill most phage and in our studies we did not observe any plaque formation in the central area. It was unlikely that a transfection process was responsible, as some of the determinants of bacteriocinogeny studied by us (see later) are likely to be autotransferable (Nomura, I967; Anderson, I968).

The genetic process therefore appears to be mediated through an extracellular diffusable agent which is inactivated by DNase but not by RNase, indicating that it is DNA. All the evidence therefore points to transformation being the gene transfer process, and the central growth of p.i. appears to be due to transformant selection in situ by the bacteriocins.

As a transformation process, p.i. is characterized by its high degree of reproducibility with respect to any particular pair of participating cultures and selectivity for BTM (vibrios only) and MPI (all groups tested, Table 2). The reaction produced by a pair of primary and secondary bacteria (Table 3 ) tested at least three times under similar conditions during the last 3 years did not vary, nor did the pattern of reaction (p.i., standard inhibition, resistance) produced by any particular primary bacterium and a given set of indicator bacteria, though the pattern could differ from that produced by other primary bacteria. The morphological characteristics of p.i. on BTM and MPI and their differences had been described earlier; an additional feature was an overall poorer central growth on BTM in contrast to the welldeveloped growth on MPI. However, most of these differences were not absolute; with certain pairs of organisms, e.g. Vibrio cholerae KII and 540, the peripheral growths and mutants within the zones of inhibition could be absent or practically so on BTM (Fig. 3), while on MPI the presence of peripheral growths could be demonstrated on only a few occasions (Fig. 4). Exceptions to this general pattern also occurred in relation to the central growths on BTM and MPI. These differences could be due to differences in the scales of production, diffusibility in the two concentrations of agar, and the final concentrations of bacteriocins in the various zones of these media. On the other hand, close similarities between the p.i. of enterobacteria and vibrios on MPI suggest close similarities between their bacteriocins and corroborate the observations of Chakrabarty et al. (1970) that the bacteriocins of vibrios, like many colicins, are easily diffusible agents and not particulate in character as suggested by Jayawardene \& Farkas-Himsley (I968).

There is no existing classification of the bacteriocins of Vibrio cholerae (cf. enterobacteria, 
Fredericq, 1957) and the inhibitory spectra of the recipient colonies could indicate single or multiple determinants of bacteriocinogeny. The inhibition patterns of the recipient colonies ( $V$. cholerae 769 , Table 6 ) belonged to five different types, only one of which resembled that of the primary ( $V$. cholerae 547). These findings suggest that the different bacteriocin factors of the donor are transferred in various combinations producing different bacteriocin types among the recipients, and their minimum number could be two. A similar pattern was observed for the recipient enterobacteria. Our studies do not suggest a linkage among these factors but since some colicin factors can mediate transfer of other colicin factors (Ozeki, Stocker \& Smith, 1962), a similar system may exist among vibrios as well.

The roles of different chemicals and constituents in the production of p.i. and transformation on BTM and MPI merit discussion. Tri-sodium citrate is an essential factor, with or without $\mathrm{K}_{2} \mathrm{HPO}_{4}$ or iodo-acetic acid (unpublished data), in the production of the bacteriocins by Vibrio cholerae (Chakrabarty et al. 1970). It is also known to protect DNA against DNase activity (Hotchkiss, I957). However, tri-sodium citrate is neither necessary for bacteriocinogeny of other bacteria (Abbott \& Shannon, 1958; Smith \& Stocker, I962; Chakrabarty, I965), nor plays any essential role in development of p.i. (Table 2). Therefore, the association of tri-sodium citrate with the development of p.i. requires explanation. On BTM, there is a high spontaneous autolytic rate of many vibrios (Wilson \& Miles, 1964) comparable to that of certain Neisseria leading to the release of transforming DNA (Jawetz, Melnick \& Adelberg, 1972) which could result in transformant formation in situ. This phenomenon coupled with a citrate-dependent bacteriocin could account for transformant production and mutant selection. Consideration of the role of the constituents of MPI suggests that SDS plays a crucial role. Two functions can be ascribed to it: (i) supporting bacteriocin production of $V$. cholerae in the absence of tri-sodium citrate, and (ii) development of p.i. for all the groups of bacteria tested. Although there is as yet no concrete indication of the mechanisms involved, for the vibrios a possible mechanism could be the release of intracellular macromolecules (bacteriocins and plasmids) as a result of the action of SDS on the cell surface(Tomoeda et al. 1968; Woldringh \& van Iterson, 1972). SDS may therefore act as an alternative to 'cold shock' (Farkas-Himsley \& Seyfried, 1962). It has been used as a lytic agent in DNA extraction procedures (Marmur, I96I; Sebald \& Véron, I963; Fox \& Allen, 1964) as well as in 'plasmid curing' tests (Tomoeda et al. I968; Salisbury et al. 1972). However, at the concentration employed in MPI $(0.05 \%)$, its lytic role is not apparent or even incipient and only occasional strains showed difficulties in growing at higher concentrations $(0.08$ to $0.09 \%)$.

The mechanism by which transforming DNA is released on BTM and MPI is not understood. It is known that many determinants of bacteriocinogeny are extrachromosomal or plasmid-linked in nature (Bhaskaran, I960; Smith \& Stocker, I962; Nomura, I967; Novick, 1969). Many bacterial cultures lose their bacteriocinogeny spontaneously (Ozeki et al. 1962; Bhaskaran, I964; Novick, 1969), although gradually; on BTM, spontaneous and substantial loss of plasmid-linked determinants of bacteriocinogeny among Vibrio cultures coupled with cellular autolysis could provide sufficient transforming DNA. The failure to develop this phenomenon on TSA or BTM by other genera may be due to an insufficient amount of donor DNA because of low spontaneous plasmid loss or autolysis. As SDS does not have any obvious lytic role on bacteria grown on MPI, the role of this and other agents in 'plasmid curing' appears to be of relevance (Tomoeda et al. 1968; Mitsuhashi, I97I; Salisbury et al. 1972; Sonstein \& Baldwin, 1972). Studies on SDS showed that it could eliminate the determinants of bacteriocinogeny from different wild and transformant (recipient) cultures at high frequencies. On the other hand, AO could eliminate these 
determinants from some of the wild and transformant enterobacteria cultures but from none of the vibrio cultures tested; failure to 'cure' the latter cultures could be due to a 'curing' dose of $\mathrm{AO}$ which was higher than the minimum inhibitory concentration for these organisms (Table 8).

The factors likely to determine the behaviour of different types of inocula on media containing various combinations of SDS and bacteriocins are: bacteriocin resistance of the bacterial population, determined by the net balance of plasmid loss and replenishment; bacteriocin concentration in the medium; and opportunities of transformation to bacteriocinogeny (Table 9). Following the application of a heavy inoculum (primary) of a bacteriocinogenic culture on MPI in the absence of bacteriocin in the medium, plasmid loss from the senescent cells due to the action of SDS proceeds side by side with plasmid replication and distribution among the young dividing cells, resulting in growth and bacteriocin production. The final growth apparently depends on the bacteriocin concentration and the frequency of occurrence of determinants of bacteriocinogeny among the population. When the same culture was inoculated on MPI in the presence of preformed homologous bacteriocin, the initial high death rate of plasmidless cells accounts for poor growth. Since there was no plasmid loss on BTM or TSA containing homologous bacteriocins (other than that due to spontaneous loss), these cultures could grow as resistant cultures. Instead, when a light inoculum (secondary) was spread out as a thin film on MPI containing homologous bacteriocins, there was a gradual loss of the plasmids and associated immunity throughout the inoculum consisting of old cells, resulting in growth failure; however, this does not apply to the cells overlying the area of growth of the primary culture, where plasmid DNA of the donor, released either spontaneously or through the 'curing' effects of SDS and available from the medium, is acquired by a transformation process. Subsequent events are summarized in Table 7. Apparently, the cells that have lost the recently acquired bacteriocin factors can continue to be viable for some time in the presence of bacteriocins. The above model is expected to hold good when the secondary inocula belong to different nonbacteriocinogenic or heterologous bacteriocinogenic cultures, making p.i. and acquisition of bacteriocinogeny at high frequencies possible (Table 3). Resistance of occasional strains was possibly due to failure of SDS to eliminate part or the whole of the plasmids and to the existence of an immunity to bacteriocins not linked with plasmids (of mutational origin). The involvement of plasmid DNA in p.i. on cell-free surfaces is easier to explain as its molecules (about 10 ${ }^{6}$ daltons; Goebel \& Schrempf, 1972) appear to be much better suited to diffusion through a layer of agar of firm consistency, than either an intact chromosomal DNA molecule (about $10^{9}$ daltons; Hayes, I968) or phage particles. The differences in the DNase susceptibility of different DNA preparations suggest that even in bacteria which carry extrachromosomal DNA, the preparations obtained by cell lysis consist almost entirely of chromosomal DNA with a small fraction of extrachromosomal DNA mixed with it (Novick, 1969); in such a situation the former may exert a 'sparing' action on the latter by competing for DNase.

The well-known transformable species of bacteria, with the probable exception of Staphylococcus, have not so far yielded any extra-chromosomal DNA elements, and genetic transformation among enterobacteria and vibrios which carry a variety of these elements is either inadequately known or unknown (Novick, 1969). However, participation of these elements in transformation was anticipated by Ravin (1961), Nomura (1967) and Jones \& Sneath (1970). Recent evidence suggests that transformation with these elements can occur among certain Gram-negative bacteria (Derylo, Buraczyńska \& Lorkiewicz, I972; Cohen, Chang \& Hsu, 1972). Our investigations show that transfer of bacteriocinogeny occurs at 
high frequency between different well-separated groups of Gram-negative bacteria by the process of plasmid mediated transformation described by us. Transformant formation in situ used by Ravin (1954) forms the basis of our tests, because p.i. and the transformation process underlying it, recognized initially among vibrios, was applied to the Enterobacteriaceae and Alcaligenes spp. It is probable that development of competence among recipient bacteria studied by us takes place in situ as in Ravin's experiments on capsular transformation (Ravin, 1954).

Transformation with extrachromosomal elements is a new approach to the problems of bacterial genetics. Further studies involving conventional and newer techniques are likely to produce interesting results.

We are grateful to the Director, Indian Institute of Experimental Medicine, and the ViceChancellor, Jadavpur University, Calcutta, for the facilities to carry out the work.

\section{REFERENCES}

Aвbott, J. D. \& Shannon, R. (1958). A method of typing of Shigella sonnei using colicine production as a marker. Journal of Clinical Pathology II, 7 I-77.

ANDERSON, E. S. (1968). The ecology of transferable drug resistance in the Enterobacteria. Annual Review of Microbiology 22, I3I-180.

BHASKARAN, K. (1960). Recombination of characters between mutant stocks of Vibrio cholerae, strain I62. Journal of General Microbiology 23, 47-54.

BhaskaraN, K. (1964). Segregation of genetic factors during recombination in Vibrio cholerae strain I62. Bulletin of World Health Organisation 30, 845-853.

Chakrabarty, A. N. (1965). A method of identification of Shigella flexneri type 6, based on colicine sensitivity pattern. Naturwissenschaften 52, 94-95.

Chakrabarty, A. N., Adhya, S., Basu, J. \& Dastidar, S. G. (1970). Bacteriocin typing of Vibrio cholerae. Infection and Immunity I, 293-299.

Cohen, S. N., Chang, A. C. Y. \& Hsu, L. (1972). Nonchromosomal antibiotic resistance in bacteria: genetic transformation of Escherichia coli by R-factor DNA. Proceedings of the National Academy of Sciences of the United States of America 69, 2 I IO-2 I I4.

CowAN, S. T. \& STEEL, K. J. (1965). Manual for the Identification of Medical Bacteria. London: Cambridge University Press.

Darrell, J. H. \& WAHBa, A. H. (1964). Pyocine-typing of hospital strains of Pseudomonas pyocyanea Journal of Clinical Pathology 17, 236-242.

Derylo, M., BuraczyŃSKA, M. \& LoRkiewicz, Z. (1972). Transformation of Col V and Col I factors. Acta microbiologica polonica 4, I53-16I.

Farkas-Himsley, H. \& Seyfried, P. L. (I962). Lethal biosynthesis of new antibacterial principle: vibriocin. Nature, London 193, I 193-I 194.

Fox, M. S. \& Allen, M. K. (1964). On the mechanism of deoxyribonucleate integration in pneumococcal transformation. Proceedings of the National Academy of Sciences of the United States of America 52, 4I2-419.

FREDERICQ, P. (1948). Actions antibiotiques réciproques chez les Enterobacteriaceae. Revue belge de pathologie et de médicine expérimentale $19, \mathrm{~S} 4,59-165$.

FredericQ, P. (1957). Colicin. Annual Review of Microbiology 11, 7-22.

Goebel, W. \& Barry, G. T. (1958). Colicin K II. The preparation and properties of a substance having colicin $\mathrm{K}$ activity. Journal of Experimental Medicine 107, 185-209.

Goebel, W. \& SCHREMPF, H. (1972). Isolation of minicircular deoxyribonucleic acids from wild strains of Escherichia coli and their relationship to other bacterial plasmids. Journal of Bacteriology xх1, 696-704.

HAYES, W. (1968). The Genetics of Bacteria and their Viruses. Oxford and Edinburgh: Elbs and Blackwell Scientific Publications.

Hirota, Y. (1960). The effect of acridine dyes on mating type factors in Escherichia coli. Proceedings of the National Academy of Sciences of the United States of America 46, 57-64.

Hotchкiss, R. D. (I957). Methods in Enzymology, vol. 3, pp. 692-696. Edited by S. P. Colowick and N. O. Kaplan. New York: Academic Press. 
International Association of Microbiological Societies, Subcommittee on Taxonomy of Vibrios (I966). Minutes. International Journal of Systematic Bacteriology 16, 135.

JACKSON, S. (1962). Genetic aspects of capsule formation in the pneumococcus. British Medical Bulletin r8, 24-26.

Jawetz, E., Melnick, J. L. \& Adelberg, E. A. (1972). In Review of Medical Microbiology, p. 40. Japan: Lange Medical Publications, Maruzen Co. Ltd.

Jayawardene, A. \& Farkas-Himsley, H. (I968). Particulate nature of vibriocin: a bacteriocin from Vibrio comma. Nature, London 2r9, 79-80.

Jones, D. \& SNEATH, P. H. A. (1970). Genetic transfer and bacterial taxonomy. Bacteriological Review 34 , $40-81$.

LEIFSON, E. (1958). Identification of Pseudomonas, Alcaligenes and related bacteria. Zentralblatt für Bakteriologie, Parasitenkunde, Infectionskrankheiten und Hygiene (Abteilung I), 173, 487-488.

MARmur, J. (1961). A procedure for the isolation of deoxyribonucleic acid from microorganisms. Journal of Molecular Biology 3, 208-2 I8.

McGeachie, J. \& MCCormick, W. (I963). Comparison of colicine production and diffusion on different solid media. Journal of Clinical Pathology 16, 278-280.

Miles, A. A. \& MisRA, S. S. (I938). The estimation of the bactericidal power of the blood. Journal of Hygiene 38, 732-749.

Mitsuhashi, S. (197I). In Transferable Drug Resistance Factor R, p. I20. Tokyo, Japan: University of Tokyo Press.

Nomura, M. (1967). Colicins and related bacteriocins. Annual Review of Microbiology 21, 257-284.

Novick, R. (1969). Extra-chromosomal inheritance in bacteria. Bacteriological Review 33, 210-263.

Ozeki, H., Stocker, B. A. D. \& Smith, S. M. (1962). Transmission of colicinogeny between strains of S. typhimurium grown together. Journal of General Microbiology 28, 67 I-687.

Ravin, A. W. (1954). A quantitative study of autogenic and allogenic transformations in pneumococcus. Experimental Cell Research 7, 58-82.

Ravin, A. W. (I96I). The genetics of transformation. Advances in Genetics Io, 6I-I63.

Salisbury, V., Hedges, R. W. \& Datta, N. (1972). Two modes of 'curing' transmissible bacterial plasmids. Journal of General Microbiology 7o, 443-452.

SChNeIDER, W. C. (1957). Determination of nucleic acids in tissues by pentose analysis. In Methods in Enzymology, vol. 3, pp. 680-684. Edited by S. P. Colowick and N. O. Kaplan. New York: Academic Press.

Sebald, M. \& Véron, M. (1963). Teneur en bases de l'ADN et classification des vibrions. Annales de l'Institut Pasteur 105, 897-910.

Smith, S. M. \& Stocker, B. A. D. (1962). Colicinogeny and recombination. British Medical Bulletin $\mathbf{x 8 ,}$ 46-5I.

Sonstein, S. A. \& Baldwin, J. N. (1972). Nature of elimination of penicillinase plasmid from Staphylococcus aureus by surface-active agents. Journal of Bacteriology III, I 52-I 55.

Tomoeda, M., Inuzuka, M., Kubo, N. \& Nakamura, S. (I968). Effective elimination of drug resistance and sex factors in Escherichia coli by sodium dodecyl sulfate. Journal of Bacteriology 95, 1078-1089.

WAHBA, A. H. (1963). The production and inactivation of pyocines. Journal of Hygiene 6r, 43 I-44I.

Wilson, G. S. \& Miles, A. A. (1964). In Topley and Wilson's Principles of Bacteriology and Immunity, p. 655. London: Edward Arnold.

WOLDRINGH, C. L. \& VAN ITERSON, W. (1972). Effects of treatment with sodium dodecyl sulfate on the ultra structure of Escherichia coli. Journal of Bacteriology $1 \mathrm{II}, 80 \mathrm{I}-8 \mathrm{I} 3$.

Zabransky, R. J. \& DAY, F. E. (1969). Pyocin typing of clinical strains of Pseudomonas aeruginosa. Applied Microbiology 17, 293-296. 